Meta

Journal des traducteurs

Translators' Journal

\title{
Literal Value and Meaning
}

\section{Leo Zawadowski}

Volume 31, numéro 2, juin 1986

URI : https://id.erudit.org/iderudit/004639ar

DOI : https://doi.org/10.7202/004639ar

Aller au sommaire du numéro

Éditeur(s)

Les Presses de l'Université de Montréal

ISSN

0026-0452 (imprimé)

1492-1421 (numérique)

Découvrir la revue

Citer cet article

Zawadowski, L. (1986). Literal Value and Meaning. Meta, 31(2), 137-144.

https://doi.org/10.7202/004639ar

Ce document est protégé par la loi sur le droit d'auteur. L'utilisation des services d'Érudit (y compris la reproduction) est assujettie à sa politique d'utilisation que vous pouvez consulter en ligne.

https://apropos.erudit.org/fr/usagers/politique-dutilisation/
Cet article est diffusé et préservé par Érudit.

Érudit est un consortium interuniversitaire sans but lucratif composé de l’Université de Montréal, l'Université Laval et l'Université du Québec à Montréal. Il a pour mission la promotion et la valorisation de la recherche. https://www.erudit.org/fr/ 


\section{LITERAL VALUE AND MEANING*}

LEO ZAWADOWSKI UNIVERSITY OF SUDBURY

\section{GLOBALITY AND ARTICULATEDNESS}

It is well known that a word has not only an informative value ( = communicative value, meaning) but also a few other values, as an associative value, an emotive value, and other stylistic values. The same holds for phrases and other constructions. Literal value results from a certain relation between the meaning of a construction and the meanings of its parts. The meaning (informative value) of a text (or text segment) may be distributed among its constituents but need not be distributed (articulated). E.g. the meaning of $\mathbf{F}$ stage is approximately the same as that of $\mathbf{E}$ training program ${ }^{1}$ but in $\mathrm{F}$ stage this content is not distributed (not articulated) :

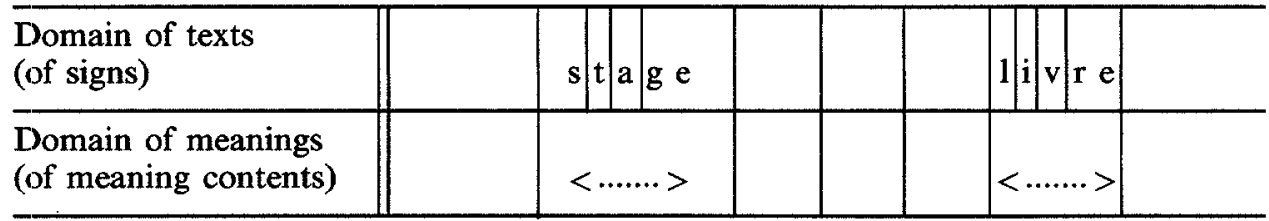

Note $:\langle\ldots .\rangle=$. the communicated content $=$ the meaning $=$ the characteristic set of features of the entity in question.

These signs are divisible but the divisions do not reach the domain of meaning contents ; this is precisely what determines that $\mathrm{F}$ stage is a morpheme and so is $\mathrm{F}$ livre. We will say that in such cases the content is communicated globally or that it is global (not articulated) with regard to the sign in question. On the contrary, in E training program the same content is distributed among the constituents of the phrase : we will say that it is articulated (with regard to the text segment in question) or that it is communicated in an articulated manner. The semantic relation (sign - meaning) is here sequentially distributive :

\begin{tabular}{|c|c|c|c|c|c|}
\hline $\begin{array}{l}\text { Domain of texts } \\
\text { (of signs) }\end{array}$ & $\mathrm{t} / \mathrm{r}$ a $\mathrm{i} / \mathrm{n}$ & $\mathrm{i} \mid \mathrm{n} \mathrm{g}$ & $\mathrm{p} / \mathrm{r}$ & or $\mathrm{g} / \mathrm{r}$ & $a \mid m$ \\
\hline $\begin{array}{l}\text { Domain of meanings } \\
\text { (of meaning contents) }\end{array}$ & $<\ldots \ldots$ & $\ldots \ldots \ldots \ldots$ & .......... & $\cdots$ & $\cdot>>$ \\
\hline
\end{tabular}

Not only the phrase (the text segment) is divisible into two main units, but to this division corresponds a division in the meaning content.

\section{GLOBALITY VS. COMPLEXITY}

There are two kinds of divisibility, viz. phenomenological divisibility and language-structural divisibility. A meaning content is phenomenologically complex and divisible when parts or components of that content can be distinguished through ordi- 
nary observation of referents of the sign in question alone, without regard to other facts of the language in question. E.g. the content $<$ tree $>$ is phenomenologically complex and divisible, the content $<$ blue $>$ is phenomenologically simple and indivisible.

Language-structural complexity and divisibility of a content is quite a different property : when the language in question possesses signs whose meanings differ by one component, those meanings are proved to be language structurally divisible, and the components which constitute the difference are found to belong to the set of basic semantic contents of the language in question (the "semes" of that language) ${ }^{2}$. E.g. E boy, E girl : the meanings of these words differ by the contents $<$ male $>,<$ female $>$ and are thus proved to be language-structurally divisible; at the same time a languagestructural component of each of them is established.

This proof is entirely analogous to the proof of morphic (formal) languagestructural divisibility of a word when e.g. E cat is proved to be composed of Immediate Morpheme Constituents [ $\mathrm{k}$, [ae], [t] by the existence of $\mathrm{E}$ fat, hat, rat, cab, fan, etc. The existence of a word (or morpheme) composed of [k] alone, of [ae] alone, etc., is not necessary. Analogously in semantic analysis it is not necessary to have words (or morphemes) whose meaning would consist precisely of the component in question as is the case with E male, E female.

The complexity and divisibility of the meaning should not be confused with its articulatedness : the informative value of $\mathrm{E}$ female child is approximately the same as that of E girl (we are disregarding the strong "stylistic" difference), but in E girl the content is global while in E female child it is articulated ; its complexity and semic composition is the same in both cases. In order to be articulated a content has to be complex, but a complex content need not be articulated : it may be global. Of course there may be different manners of articulation of a meaning content and the manner of articulation (or absence of articulation) is an important factor in communication and consequently in translation.

\section{SEMIC RELATIONS AND SEMICALLY REGULAR CONSTRUCTIONS}

A necessary condition for the existence of a grammatical construction is the presence of morphic (formal) grammatical relations between two (or more) morphemes. Grammatical relations are categorial conventional cooccurrential relations between morphemes (or constructions), as in we work, they worked, we talk, they talked. Such constructions may also be called morphically regular grammatical constructions.

Domain of texts we talk
(of signs)

\begin{tabular}{|c|c|c|c|}
\hline $\begin{array}{l}\text { Domain of } \\
\text { meanings }\end{array}$ & $\begin{array}{l}\text { straight } \\
\text { meanings }\end{array}$ & $<\mathrm{I}+$ others $^{1}$ & $\begin{array}{c}2 \\
<\text { action of talking }>\end{array}$ \\
\hline $\begin{array}{l}\text { (of meaning } \\
\text { contents) }\end{array}$ & $\begin{array}{l}\text { oblique } \\
\text { meaning }\end{array}$ & $<1$ is a feature & ) of $2>$ \\
\hline
\end{tabular}

Besides morphic relations there exist semic relations. It has been stressed by Saussure that a construction is not a sum of two morphemes but a combination which he calls their product ; not désir + eux but désir $\mathrm{x} e u x^{3}$. This remark may well have referred to what we now state with regard to the meaning of a construction : the meaning of a construction is not a sum of the meanings of its constituents but a structural whole consisting of the meaning contents of its constituents and a communicated conventional 
relation between these meaning contents ${ }^{4}$. E.g. the meaning of $\mathrm{E}$ we talk is not : $<(\mathrm{I}+$ others) + (action of talking) $>$ but :

It is seen that in the total meaning of a construction two layers should be distinguished : 1) the straight meaning contents of the constituents, found in virtue of alternation with you, he, etc. and with work, play, etc. respectively ;2) a relation between the straight meaning contents $=$ the oblique meaning content $=$ the internal relational content. As in this case all these factors are categorial (regular) the total meaning content of each construction above is regular and consequently entirely predictable. The construction is semically regular. A grammatical relation between two morphemes (words, etc.) consisting in the fact that their straight meanings are so and so categorially related in a collocation is called a semic relation. Thus there is a semic relation between the morphemes $1(I$, you, etc.) and 2 (work, talk, etc.) resulting from the internal relational content described above. As that internal relational content is here categorial, the semic relation between the morphemes in question is categorial too (regular).

\section{SEMICALLY IRREGULAR CONSTRUCTIONS AND PROJECTED VALUE}

However, surprisingly many of the morphically regular constructions are semically more or less irregular. In the case of some categories of constructions just one of the many members of a category exhibits this kind of irregularity. This situation is particularly frequent above the level of the word : in compound words, word groups, and sentences. Let us consider the following constructions :

Il se payait sa tête (= l'exposait au ridicule; le trompait)

He is pulling your leg (=il vous met en boite).

The actual meaning of these constructions does not result from the meaning contents of their constituents combined according to the ordinary semic relations, i.e. those proper to the category of constructions in question (a transitive verb in a Finite form, a direct object, etc.) : the constructions are semically irregular. Their meaning is unpredictable and conventional (as is seen from the difference between the ordinary meanings of the constituents in $\mathrm{E}$ and in $\mathrm{F}$, and within $\mathrm{F}$ ). Consequently these constructions are part of the languages in question, viz. of their lexicon - they are "lexemes" exactly as any lexical morpheme; only they are complex lexemes.

Moreover, the irregularity of the actual meaning is such that the actual meaning cannot be derived from the constituents, even if an entirely deviant meaning were ascribed to them and said to be proper to them in this particular collocation : the actual meaning is global (of course excluding e.g. F il, or $\mathrm{E}$ is, which do not belong to the irregular part of the sentence). With regard to this global meaning, the particular words play the constitutive and diacritical role, exactly like phones with regard to a morpheme : like phones do not communicate any part of the meaning of a morpheme, so these words do not communicate any content that would be part of the actual meaning of the construction.

However, the irregularity and conventionality of the actual meaning (and in this case also : its globality) cannot abolish the normal effect of the presence of the constituent words : even while they do not communicate any part of the actual meaning of the construction they do communicate their normal (regular) meaning contents ; and these contents are combined according to the categorial semic relation proper to the category of constructions in question. That is to say : along with the actual meaning content of the sentence ( $<$ il l'exposait au ridicule $>$ ) another sentence-content is transmitted, viz. the content which would be the meaning of the collocation if it were not for the semic irregularity of this particular collocation : this content is called non-technically and currently the literal value of the collocation. 
We say value not meaning, because it is not the informative value (= meaning) of the collocation, and the users of the language are well aware of it; nevertheless it is a content which can be exactly established and which is inevitably transmitted whenever the collocation in question is used. What is called the literal value is a projection of categorial semic facts (normal meanings of constituents and normal internal relational content) onto the one collocation that deviates from them : it is a projected value (projected content) or an extrapolated value. However, not all projected values are categorial. In the case in question the projected value is the categorial value of the collocation.

\section{QUASI-LITERAL VALUE}

Irregular constructions are often referred to by the term idioms ${ }^{5}$. This term is illdefined but certainly much broader and includes expressions which have neither anything irregular nor anything like a literal value, e.g. constant use of certain expressions in certain situations, like greetings, exclamations, etc. In this broad sense AmE $h i$ ! and F Olàlà ! are idioms. As far as constructions are concerned the term idioms refers, or may refer, not only to semically irregular constructions defined above but also to the constructions of the following type :

Les arbres cachent la forêt.

He does not see the forest on account of trees.

Il ne se laisse pas marcher sur les pieds.

On a ménagé la chèvre et le chou.

La sauce fait passer le poisson.

It would seem that these idioms also have a literal value that differs from the actual meaning. It may be conceded that each of them offers two contents : one that results from the ordinary meaning of the constituents (regular content) and a somehow "superimposed" content. When such an idiom is used it looks like the "superimposed" content is the one "intended", so that the regular content somehow looks like a "literal value". But in these idioms there does not seem to be any irregular semic relation. What is in reality their differentia specifica?

We could first use an intuitive clue : the "superimposed" ("intended") value can be found out without the knowledge of the language in question, as soon as their regular content is known (it is sufficient to have a translation of the text); it is not necessary to learn them. It would follow that the superimposed ("intended") value is not conventional. And this is actually the case, or at least there is but a slight degree of conventionality. For the relation between the two values is either one of metaphor (examples above) or of an explicit comparison, as in :

F (on l'a reçu) comme un chien dans un jeu de quilles.

$E$ (...) like a bull in a china shop.

Now these are non-conventional relations, known to everybody who knows the world in which we live (as the relation between a goat and a cabbage) or some broad features of human civilization (as the relation between sauce and fish in a meal). In some cases these relations are limited, as to their occurrence, to a specific (not universally human) culture, as in

Il n'a pas mis de gants pour lui parler (= spoke without consideration or courtesy)

or even may be so limited as to have its extension coincide with that of a language community, but that is entirely different from a relation imposed by a convention of a language itself. It is true that such limitation constitutes a factor of conventionality, albeit weak. Another factor of conventionality consists in the fact that in a comparison the choice of terms of comparison is to some extent free, and a particular choice made and 
institutionalized in the expressions in question is consequently, to an extent, conventional, even if the relation chosen is universal. This is seen particularly clearly when in different languages different choices for the same content are institutionalized, as in the case a bull in a china shop and un chien dans un jeu de quilles, or

$\mathrm{F}$ Elle appelle un chat un chat

E She calls a spade a spade.

The institutionalization (and hence conventionality) usually extends not only to the kind of the thing in question (goat, bull, dog, shop with breakables, etc.) but also to the words used. E.g. : F Elle a brûle ses vaisseaux.

Vaisseaux cannot here be replaced by a synonym, e.g. navires or bateaux. And analogously in other examples quoted above.

The very low degree of conventionality of the "idioms" dealt with in this section gives them a character analogous to symbols as opposed to fully conventional signs. Saussure strongly insisted on the non-conventional character of symbols, resulting from their extra-linguistic relation (lien naturel) to what they represent : "Le symbole de la justice, la balance, ne pourrait pas être remplacé par n'importe quoi, un char par exemple ${ }^{6}$." The reality is less simple : symbols have a (slight) degree of conventionality" in that one of several possible is institutionalized.

Accordingly, these slightly conventional "idioms" definitely differ from semically irregular constructions. In the latter the actual meaning, semically irregular, is fully conventional : it cannot be ascertained from universal facts or from facts of the culture in question. In the case of slightly conventional "idioms" we have not even been able to use the term meaning with regard to their "superposed" (and "intended") value, because that value is only slightly conventional. They exhibit a contrast between that "superposed" value and a quasi-literal value resulting from the ordinary meaning of the constituents combined according to ordinary grammatical laws (of the language in question). But the status of these two values and the relation between them is different than in semically irregular constructions.

In the semically irregular constructions the semically regular content is not the meaning of the construction but a shadow value (literal value) projected onto the real meaning, superposed on it ; the superposed value is the actual meaning, because it is the only content actually communicated and that communication is effected by conventional means. In the slightly conventional "idioms" the regular content remains the actual meaning-content ( $<$ like a bull in a china shop $>,<$ he didn't put on gloves to talk to him $>$ ). It is the hearer, not the language, who superposes on the meaning another content ( $<$ "clumsily" >, <"brutally" >, etc.), formed by a non-conventional inference from the regular content (in the case of a formal comparison, as in the examples above) or by "resolving" the metaphor. The latter is also a non-conventional proceeding : in virtue of a universally human rule (proper to the use of all languages) every sign has a second meaning $<$ like $\mathbf{x}\rangle$ besides its standard meaning $\langle\mathbf{x}\rangle$; that is to say, every sign is polysemous and one of the two meanings has to be selected by context or consituation. The meaning $\langle\mathbf{x}\rangle$ is the standard ("unmarked") meaning; the meaning $<$ like $\mathbf{x}\rangle$ is marginal, and requires the presence of special factors to be selected, but is a legitimate choice. In the case of he didn't put on gloves the second meaning is < he didn't do anything like putting on gloves $>$ and this meaning is easily selected by context and (or) consituation. From this regular meaning, by non-conventional inference, the content $<$ (he spoke) "brutally" > is inferred.

It is seen that whether it is a formal comparison or a metaphor the superposed content is obtained by non-conventional inference and cannot be considered as the meaning of the construction (its informative value), whatever the obviousness of its be- 
ing "intended" by the speaker. The meaning of the construction is its regular informative value. The speaker can intend to have the "superposed" information-content transmitted to the hearer (while he pronounces a construction which only communicates a premise of that content) precisely because he feels that the hearer will "obviously" pass from the premise to the conclusion. And the hearer can do that because the relation between the two is non-conventional, as proved by the fact the same effect will be achieved if the construction is formed in another (in any other, in fact) language.

This crucial fact is not changed by the fact that the two contents are held together by a slight degree of conventionality in the choice of terminals of comparison (or of metaphor) : in order to transmit metaphorically the content <"brutally" > one is prompted to speak of gloves, and, conversely, the use of the saying about gloves, etc. consistently makes the hearer infer the content <"brutally" >. If one wishes to insist on this slightly conventional character of the link between the two contents one can possibly say that the regular meaning of the construction acquires here a role of quasi-literal value.

\section{TEXTUAL EXTENSION AND DEGREE OF IRREGULARITY}

When somewhere in a sentence a literary value (as opposed to the meaning) is observed, the irregularity is usually confined to a part of the sentence - to a constituent construction. It is sufficient that one of the constituents of that construction has an irregular (exceptional) meaning, e.g. un haut fourneau (E blast furnace or smelting furnace), un petit pain, les grands magasins, misère noire (E squalor). In these phrases the meaning of the adjective is irregular. The irregularity is thus found to be primordially located on the level (degree) of morphemes. It would be also sufficient that the internal relational content be irregular; the irregularity would be then located on the level of the construction resulting from the irregular grammatical relation.

To avoid confusion it is necessary to distinguish 1) between the irregular construction (haut fourneau) and the primordial irregular factor, which we found to be haut, petit, etc., and 2) between the irregular construction and its regular context. There is a delicate relation between the irregularity of haut and that of haut fourneau. On one hand haut has this kind of semantic irregularity only when in collocation with fourneau, so that fourneau is so to speak the inducer of irregularity ; on the other hand it is only haut that is irregular, not fourneau (for a smelting furnace is a furnace, content carried by fourneau, while haut carries the content $<$ smelt(ing) $>$. Thirdly, the irregularity brought by haut makes the construction haut fourneau semically irregular and gives it a literal value. An essential difference : fourneau is the syntagmatic condition of the irregularity of haut, while haut "makes" haut fourneau irregular by introducing its irregular meaning into the construction through the grammatical relation between the two constituents, a relation (viz. : Adjective - Noun) which is in this case entirely regular. Irregularity is thus brought to the level of higher sentence constituents, viz. of phrases ; but it is not primordial irregularity any more.

To the point (2): the irregularity does not go any further, as the grammatical relation between haut fourneau and the rest of the sentence does not depend on the lexical meaning of haut fourneau. We have thus established the limits of irregularity - and of the resulting literal value - on the sequential text axis (sequential delimitation of irregularity), and through this - on the scale of degrees of text constituents (as phone, morpheme, word constituent, word, phrase, etc.). We have also established the distribution of irregularity among the elements of the text in question (a sentence containing haut fourneau) and the character of irregularity exhibited by the particular elements. Another essential point in the description of semic irregularities is the divergence between the irregular actual meaning and the literal value. A relatively slight degree of 
divergence occurs when the actual meaning is just a narrowing down of the literal value (e.g. haut fourneau), which is the most frequent case. There may be also an extension of the literal value (or of a part of it), or a shift with regard to the literal value. The shift may be such that it is not possible any more to ascribe any part of the actual meaning to any one of the constituents or to the internal relational content : in such cases the irregular actual meaning is global (unarticulated).

We propose to examine the play of these (and other) factors in a few constructions with literal value.

Pour lui elle était la pluie et le beau temps (= was his all ; filled his universe ; decided about everything).

The irregularity is confined to la pluie et le beau temps, but être or another copuloid verb (devenir, sembler, etc.) in any form (incl. Infinitive) as well as pour + indication of person (or an equivalent) are necessary for the irregularity ; one of the consequences is that la pluie et le beau temps has to be the Nominal Predicative (F attribut) : otherwise, the meaning is identical with the literal value ${ }^{7}$. This is again the interesting case when the syntagmatically inducing factor of irregularity is outside the irregular construction and functions as a selector of the irregular meaning to be applied and as a diacritic of the irregularity of the nominal phrase. The irregular meaning is global. It is also slightly non-conventional ; this does not diminish the completeness of the globality.

An analogous case : Il lui dit des noms d'oiseaux (= dire des injures).

The irregularity is confined to noms d'oiseaux, and here, too, the inducing factor is outside : the verb dire in any form (incl. Infinitive) accompanied by the necessary pronouns, so that des noms d'oiseaux is the Object to dire. The meaning is global as the insults need not be names ( $\mathrm{E}$ to call sb. names should not mislead us).

Similarly : Je vous ai fait faux bond (break one's promise ; "stand sb. up").

The irregularity may be considered to be confined to faux bond on account of the generality of faire (faire une faveur, faire de la peine, etc.); faux bond would then mean $<$ a disappointment as to a promise or as to an appointment $>$. The fact that in $\mathrm{E}$ to stand him up an equivalent of the meaning of faire is included in the irregularity should not mislead us. If faire is included in the irregularity, the case belongs to a category dealt with below.

There are global idioms with a more complicated meaning, viz. exceeding the limits of one sentence constituent (as the nominal phrases above). This is the case in : Il s'est payé ta tête.

The irregularity extends to the complex : the verb se payer (in any form incl. the Infini.) + tête (with a Determinant). The grammatical morpheme of payer and the determinant of tête do not participate in the irregularity. The irregularity comprises thus two lexical morphemes belonging to two distinct sentence constituents (Verb and Object) and standing in an appropriate grammatical relation. The meaning is global and that grammatical relation is included in the globality : in the meaning there is no trace of the verb-object relation corresponding to payer and tête; the latter complex, alone and unarticulatedly, communicates the kind of relation in question with regard to somebody ( $<$ se moqu->).

A similar case : Elle lui a posé un lapin ("stood him up").

The irregularity comprises poser (in any form, incl. Infin.) le lapin, i.e. two lexical morphemes and a relation Verb - Direct Object between the words in question, but that relation disappears in the global meaning along with the regular meanings of the two morphemes.

In the semically irregular constructions studied above the meaning is global but the text is - of course - articulated ; moreover it is morphically regular, which is a 
condition of the existence of a clear literal value. But the institutionalized text of a global construction is highly redundant with regard to the meaning and is liable to undergo attrition, which may make it first morphically irregular, and then morphically global, too. The result will be expressions like courir la prétentaine and à la queue leu leu. The former is still morphically articulated but the second constituent has now no meaning of its own at all and is never used outside the construction quoted, so that the literal value is actually lost ; courir brings a trace of an associative value into the practically global meaning. $\dot{A}$ la queue leu leu has only a deformed trace of morphic articulation, and its literal value is lost : the text is still divisible but not regularly articulated ; the meaning, of course, is completely global.

* Colloque de Glendon, 1980.

\section{Notes}

1. This English translation is a little simplified for a $F$ stage is not just a training program : it is a special training program (e.g. an ad hoc training program and one for basically qualified people, etc.). Besides, $\mathrm{E}$ program here refers to more than a program, viz. to an organized series of units of instruction.

2. See Leo Zawadowski (1975) : Inductive Semantics and Syntax - Foundations of Empirical Linguistics, The Hague, Paris, Mouton, pp. 77, 208, 245.

3. CLG, p. 256 of orig., p. 176 in De Mauro ed. of 1975.

4. L. Zawadowski, op. cit., pp. 160 sqq.

5. In French often : idiotismes, which can be easily replaced by idiomatismes. With reference to French idioms, mostly gallicismes.

6. Cours de linguistique générale, p. 139 of orig., p. 101 in Tullio de Mauro ed. (1975) : Paris, Payot.

7. There is also another irregular meaning, viz. in the construction parler de la pluie et $d u$ beau temps. 